\title{
The Effect of Teaching English Using Realia Media on Students' Speaking Ability
}

\author{
Uchy Mukho Adrianty \\ Universitas Negeri Padang \\ email: uchymukhoadrianty@gmail.com
}

\begin{abstract}
This goal of this study was to see if there was any significant effect on students' speaking achievement after they were taught using Realia media at MTs Muhammadiyah 1 Pekanbaru. This quantitative research method used a pre-experimental design. The technique of collecting the data used total sampling. It took one class; the eighth grade as an experimental class that consisted of 12 students. The researcher administered one time of pre-test, six times of treatments, and one time of post-test. Wilcoxon Signed Rank Test was used to analyzed the data and the hypothesis testing was analyzed by using SPSS version 20.00 at the significant level of $p<0.05$. The mean score increased from 43.42 up to 60.92 . The result of hypothesis testing showed that the significant (2-tailed) is $p$ value $=0.003$ and the level of significance is if $\mathrm{p}$ value $<0.05$. It means there was a significant effect on students' speaking achievement after they were taught by using Realia.
\end{abstract}

Keywords: Speaking Achievement, Realia Media, English Teaching

\section{Introduction}

In English language teaching, the learners need to master four language skills they are reading, listening, writing, and speaking. According to Davies \& Pearse (2000), the primary goal of English language instruction is to prepare learners with the ability to communicate effectively and appropriately in English. The researcher focuses on speaking ability among English skills since it allows students to convey their ideas, emotions, and feelings orally in a foreign language. According to Amumpuni (2019), students must practice their skills in daily activities in order to develop their speaking ability. As a result, teachers should provide more opportunities for students to practice speaking skills by providing additional examples, activities, methods, and media that allow them to engage in real-world communication. According to Brown (2000), speaking is a productive skill that can be directly and empirically observed. Speaking helps the students to communicate with each other. People share their idea and opinion by speaking with expecting feedback from their listeners. According to Siregar and Anwar (2019), speaking is the activity to express or to deliver thought and feeling orally. Meanwhile, speaking as the process of transmitting ideas and information orally in a variety of situations. It is important to practice speaking on a regular basis, yet students may encounter difficulties when doing so. They are unable to convey their views orally and their communication is misunderstood. It's also jerky, slow, and disjointed. In teaching English, especially in teaching speaking, this difficulty cannot be separated from technique, strategy, method, and media use. As a result, it is recommended that the teacher prepare these components, particularly the use of media in the classroom.

Once it comes to teaching speaking, media plays an important role in assisting the learning process. According to several experts, they stated that a medium is a communication vehicle (as an media for tecahing instruction). The goal of media is to make communication easier (instruction). A "Medium" is defined by Merriam-Collegiate Webster's Dictionary (1993) as "tools" for communicating information. 
Sudrajat, as cited in Schramm (1977) stated that media is a medium for spreading information and can be used to supplement learning. The tangible object used to transport learning materials such as books, films, and videos is referred to as media. According to the theories, tools that deliver a message and excite students' cognitive, emotional, and motivational processes are critical to the English learning process. Graphics, charts, cartoons, radio, tape recorders, overhead projectors, television, and even everyday objects can be used as media in today's world. In line with, Chan, et al (2011), the capabilities of a medium enable approaches and the methods employed by teachers to take advantage of these capabilities. It means he believes that media can influence the learning process. If the media are going to influence learning, the method must be suitable for the medium. So, success in learning depends on the methodology and medium capabilities that teachers use. Two kinds of media as Technical media and Non-Technical media are often used by the teacher in teaching and learning (Chan, et al, 2011). Using visual aids is one of the media that can be used by the teacher. One form of Non-technical media used for learning is called realia or real object. Jonassen et al (1944) cited in (Chan, 2011) stated that media are more important as a vehicle of learning and can be used more productively as tools to support learners' to allow them to focus fully on the knowledge.

From the preliminary research at the second semester of the students of MTs Muhammadiyah 1 Pekanbaru that the students have some weaknesses in English learning moreover in their speaking ability with some reasons, the researcher found several phenomena at the eighth grade, as follows: (1) The students have lack vocabulary so that they had difficulty to speak in English, (2) The students are not able to communicate in English while the process of learning, (3) The students can not pronounce and spelling the words well. In addition, many students did not reach a good score yet. It was caused some students do not like speaking activity. Then the students' also difficult to speak if the teacher asks them to explain things. In the middle level, speaking is one of the most important elements to be acquired in teaching and learning activities. Curriculum 2013 includes speaking as one of the abilities in English mastery that must be taught and developed in school in order to meet students' demands on speaking.

In education, realia are objects from real life used in EFL classroom instruction to improve students' speaking ability. The word of realia refers to any items, things, or facts that are found in everyday real-life and used as a tool in teaching the English language (Bala, 2015). Realia also makes the learning process more enjoyable (Harmer, 2001). According to Soames (2010) stated that realia as a tool using real objects or items found in every life as an aid to teach English. It refers to realia are everyday objects that may be found in our environment and will be used in classroom training to help students develop their speaking skills. Realia will be utilized to connect learners with the essential focal point of a lesson by permitting a multi-dimensional relationship between learnt material and the lesson object, according to (Amumpuni \& Rahmasari, 2019). Realia are very helpful in the learning process because they are not only interesting and motivating for EFL students but they are also considered as a powerful connection that creates a pleasant learning experience and positively influences the learners in the classroom through the diversity of language functions and tasks. In addition, Harmer (2001) states that realia or real objects are useful for teaching and learning in the classroom. Intrinsically, interesting objects provide a good starting point for a variety of language work and communication activities. Realia is suitable for every English lesson topic and for students of any level, from beginning to advanced. One technique to pique students' interest in teaching and studying English is to use Realia. Because realia involves real objects that are brought into the classroom, it might stimulate pupils to communicate their thoughts and ideas vocally. It lets pupils to see or hear the material, and in some situations, they can even touch it.

The previous studies have examined Realia media in the process of teaching and learning activities. For instance, the study conducted by Hadi (2018) about the Effectiveness of Using realia in Teaching English Vocabulary for ESL Learners'. Then, the study conducted by Amumpuni (2019) about Enhancing Students' English Ability by Using Realia. The next study was conducted by Mulyani (2015) about The Use of Realia to Improve Students' Speaking Skills. Then, the other study conducted by 
Harmawan and Amri (2018) about Using Realia to Improve Students' Speaking Ability in Junior High School. The last study was conducted by Rokhmawati (2011) about The Use of Realia to Improve Students' Speaking Ability in Procedure Text.

Therefore, the researcher is interested to apply media is called realia. This study uses realia as the medium to test students' English learning especially speaking ability in practicing the language. An idea comes from an expert (Harmawan \& Amri, 2018) stated that "The use of realia as media in the learning process will make its process more memorable and enjoyable because students are allowed to use their senses". In the line with these statements, Realia, as according Hunt and Beglar (1998), can benefit learners because they not only hear but also see the word. Considering visual aids, French (1983) claims that "actual objects are preferable than photographs anytime we have them in the classroom." It is assumed that while referring to real objects in the classroom, French is referring to windows, doors, walls, floors, tables, clocks, and other such items. Real items, according to this author, are more accessible and less expensive than any other resource.

The researcher describes the concerns described in the following prepared the main objectives of this research as stated as follows: The first is to measure the score of students' speaking ability before being taught by using realia. The second is to measure the score of students' speaking ability after being taught by using realia. The third is to know whether there is any significant effect on students' speaking ability before and after being taught by using realia.

\section{Methods}

The method of this quantitative research is used experimental research. According to Creswell (2012), the experimental design is used to test an idea (material, practice, or technique) to see if it has an effect on the outcome or the dependent variable. Experimental designs are processes used in quantitative research to examine whether a particular activity or substance affects the outcome of students as participants. The researcher conducts a pre-experimental design, where the researcher uses a one-group pre-test-post-test design (Sugiyono, 2011). This research does not use a comparison class but has already used a preliminary test so that the magnitude of the effect or effect of the use of media realia can be known with certainty. According to Ary, Jacobs, Sorensen \& Razavieh (2010), the first phase in a onegroup pre-test-post-test design is to administer a pre-test that measures the dependent variable; the second step is to apply the experimental treatment to the participants; and the third step is to conduct a post-test that measures the dependent variable again. By comparing the pre-test and post-test scores, the differences ascribed to the experimental treatment's application are analyzed. There isn't a control group in this study's design. The researcher investigates the impact of reality media on students' ability to communicate. Students take a pre-test before receiving treatment from the researcher. The researchers then administer a post-test to the students.

The population of this research was eighth-grade students of MTs Muhammadiyah 1 Pekanbaru in the academic year of 2020/2021. The population consists of 1 class. In this research, the researcher takes the sample by using total sampling. In line with Sugiyono (2007), total sampling is a sample technique in which the number of samples is equal to the number of people in the population. Because the total number of populations in this study is less than 50, the researcher decided to use total sampling in preexperimental research. The overall sample size for this study is 12 students, all of whom are from the same class.

In collecting the data, the researcher took the data by using a test. A speaking test was employed in the assessment. The speaking test is designed to gather information about a student's capacity to communicate. The students offered their thoughts on the assigned topic. The researcher used a rubric taken from the teacher's English book grade eight provided by Curriculum 2013 to rate the eighth-grade students' speaking skills at MTs Muhammadiyah 1 Pekanbaru. Pronunciation, vocabulary, grammar, 
fluency, and comprehension are the five qualities of speaking that are evaluated. The researcher provided each group a pre-test and a post-test in this study.

Table 1. Assessing Speaking Ability: Components

\begin{tabular}{|c|c|c|}
\hline Aspects & Score & Requirement \\
\hline \multirow{3}{*}{ Pronunciation } & 1 & Incomprehensibly spoken words \\
\hline & 2 & Even if the pronunciation is poor, the message is clear. \\
\hline & 3 & Speaking with a number of misspellings \\
\hline \multirow{6}{*}{ Grammar } & 4 & Pronounce everything correctly. \\
\hline & 1 & $\begin{array}{l}\text { Many grammatical errors make meaning too difficult to understand } \\
\text { and often repeating sentences. }\end{array}$ \\
\hline & 2 & Frequently make grammatical errors that affect meaning. \\
\hline & 3 & Sometimes making errors but do not affect the meaning \\
\hline & 4 & Has a little bit of grammatical errors \\
\hline & 1 & Using an incorrect vocabulary that is difficult to understand. \\
\hline & 2 & Has a limited vocabulary to speak \\
\hline \multirow[t]{2}{*}{ Vocabulary } & 3 & Choice of the words that could almost be understood \\
\hline & 4 & Using the exact words without hesitation \\
\hline \multirow[t]{4}{*}{ Fluency } & 1 & With a lot of pauses, I'm speaking. \\
\hline & 2 & Too sluggish of a delivery \\
\hline & 3 & Generally speaking at a reasonable pace \\
\hline & 4 & Fluent in English \\
\hline \multirow[t]{4}{*}{ Comprehension } & 1 & The message is difficult to understand due to major speech flaws. \\
\hline & 2 & $\begin{array}{l}\text { Understands things very slowly and usually leads to } \\
\text { misunderstandings. }\end{array}$ \\
\hline & 3 & Although there are flaws in the message, it is understandable. \\
\hline & 4 & $\begin{array}{l}\text { The faults in speech are modest, and the message would be simple } \\
\text { to understand. }\end{array}$ \\
\hline
\end{tabular}

Explanation:

The score Total $=20$

Value Practice $=$ Score achievement $/$ The score total $\mathrm{x} 100$ 
Before to using realia in teaching speaking, the subject is given a pre-test. Meanwhile, after using realia to teach speaking, the post-test is given. The test explained in the procedures of collecting data for the experimental class as follows:

1. Pre-test

Before they were taught utilizing realia media, students were given a pre-test to assess their speaking skills. This pre-test was given before the researcher began training speaking with realia. Its goal is to determine a student's speaking abilities.

2. Treatment

Six meetings were held to conduct the teaching and learning process using realia media. The researcher, as a teacher, treats the students by using realia in every teaching speaking in the classroom throughout the school.

3. Post-test

After the treatment, a post-test was given. The items in the post-test are the same as those in the pretest. When administered in a classroom, pre-test and post-test have some utility. The goal of this post-test was to determine the students' ability to communicate.

To find out whether there was a significant effect or not, the researcher used a statistical method. In addition, the type of pre-experimental research is for one group pre-test-post-test, so the data was analyzed by paired samples test. Because the data in this study did not have a normal distribution, the researchers utilized a non-parametric test. The Wilcoxon paired-sample test was then employed by the researcher (Wilcoxon one-sample signed-rank test). If the dependent variables' ordinal or parametric assumptions are obviously violated, Wilcoxon Signed Rank is utilized (Leech, 2005). The data was calculated using the SPSS application 20.0 version to see if there was a significant difference in students' speaking ability between utilizing and not using guided Realia media.

\section{Result and Discussion}

1. The Score Classification of Students'Ability in Speaking before being Taught by Using Realia

Table 2. Speaking Ability before being Taught by Using Realia

\begin{tabular}{ccccc}
\hline No & Categories & Score & Frequency & Percentage \\
\hline 1 & Very Good & $90-100$ & 0 & $0 \%$ \\
2 & Good & $76-89$ & 0 & $0 \%$ \\
3 & Enough & 75 & 0 & $0 \%$ \\
4 & Less & $<74$ & 12 & $100 \%$ \\
\hline \multicolumn{2}{c}{ Total } & & 12 & $100 \%$ \\
\hline
\end{tabular}

It can be seen from the table above that no student was in the very good category, with a percentage of $0 \%$. Then, with a percentage of 0 percent, no student was in the good category. There was no student with in the enough category, with a percentage of $0 \% .12$ students were in the lower category, with a $100 \%$ success rate. Based on the previous explanation, the researcher determined that before being taught using Realia, the average score of the students' ability to speak especially in describing the favorite things was in the lower category.

2. The Score Classification of Students' Ability in Speaking Before Being Taught by Using Realia

Table 3. Speaking Ability after being Taught by Using Realia

\begin{tabular}{ccccc}
\hline No & Categories & Score & Frequency & Percentage \\
\hline 1 & Very Good & $90-100$ & 0 & $0 \%$ \\
2 & Good & $76-89$ & 2 & $16,7 \%$ \\
\hline
\end{tabular}

Language Learning Innovation in Pandemic Covid-19 Era

http://icolp.fbs.unp.ac.id/ 
DOI: https://doi.org/10.24036/icolp.v1i1.19

\begin{tabular}{rcccc}
\hline 3 & Enough & 75 & 0 & $0 \%$ \\
4 & Less & $<74$ & 10 & $83,3 \%$ \\
\hline & Total & & 12 & $100 \%$ \\
\hline
\end{tabular}

As can be seen from the table above, there was no student in the very good category, with a percentage of $0 \%$. There were two students in the good category, with a percentage of $16,7 \%$. There was no student in the enough category, with a percentage of $0 \%$, and 10 students in the less category, with a percentage of $83.3 \%$. Based on the above mentioned explanations, the researcher determined that after being taught using Realia, the average score of the students' ability to speak was in the less category.

\section{The Data Analysis of the Effect of Realia on Students' Speaking Ability}

The data of students' ability in speaking after being taught by using Realia were obtained from the students' pre-test and the students' post test score. The statistical description of students' pr-test and posttest score were described as follows:

Table 4. The Descriptive of Pre-Test and Post-Test Class

\begin{tabular}{lcccccc}
\hline \multicolumn{7}{c}{ Descriptive Statistics } \\
\hline & $\mathrm{N}$ & Minimum & Maximum & Sum & Mean & Std. Deviation \\
Pre & 12 & 30 & 68 & 521 & 43,42 & 14,184 \\
Post & 12 & 30 & 88 & 731 & 60,92 & 16,632 \\
Valid N & 12 & & & & & \\
(listwise) & 12 & & & & \\
\hline
\end{tabular}

According to tha data from the table above, there were a total of 12 students in the class. The students' pre-test mean score was 43.42, and the students' post-test mean score was 60.92 ; the students' pre-test standard deviation was 14.184, and the students' post-test standard deviation was 16.632. Students received a minimum score of 30 on the pre-test and a minimum score of 30 on the post-test. Meanwhile, the maximum pre-test score for students was 68 , while the maximum post-test score for students was 88 .

After knowing that the data were not normally distributed, the researcher would show the description of Wilcoxon Signed Rank Test analysis as follows:

Table 5. Data Analysis of Wilcoxon Test

\begin{tabular}{|c|c|c|c|c|}
\hline & Ranks & & & \\
\hline & & $\mathrm{N}$ & Mean Rank & Sum of Ranks \\
\hline & Negative Ranks & $0^{\mathrm{a}}$ &, 00 & ,00 \\
\hline & Positive Ranks & $11^{\mathrm{b}}$ & 6,00 & 66,00 \\
\hline Post Test - Pre Test & Ties & $1^{\mathrm{c}}$ & & \\
\hline & Total & 12 & & \\
\hline a. Post Test $<$ Pre Test & & & & \\
\hline b. Post Test $>$ Pre Test & & & & \\
\hline c. Post Test $=$ Pre Test & & & & \\
\hline
\end{tabular}

In order to know the significant difference between pre-test score and post-test score, the analysis was continued as follows: 
DOI: https://doi.org/10.24036/icolp.v1i1.19

Table 6. Significant Effect between Pre-Test and Post-Test Score

\begin{tabular}{lrr}
\hline & Test Statistics $^{\text {a }}$ & \\
& & Post Test - Pre Test \\
\hline$Z$ & $-2,950^{\text {b }}$ \\
Asymp. Sig. (2-tailed) &, 003 \\
$\begin{array}{l}\text { a. Wilcoxon Signed Ranks Test } \\
\text { b. Based on negative ranks. }\end{array}$ & \\
\hline
\end{tabular}

Based on the output SPSS above, Wilcoxon-Signed Rank Test shows the asymp significant value: Ho: Variance Population identical Ha: Variance Population not identical If Probabilities $>0.05$, Ho is accepted If Probabilities < 0.05, Ha is accepted

According to the SPSS output, $\mathrm{Ha}$ is acceptable since $0.003<0.05$. It means that the population's variance is not the same. The sig (2-tailed) value can also be observed in the output above, which is 0.003 . It is possible to declare that $0.003<0.05$. It indicates that the null hypothesis (Ho) is rejected and the alternative hypothesis (Ha) is accepted. It is clear that Ha has been accepted and Ho has been refused.

In conclusion, teaching speaking after using realia at MTs Muhammadiyah 1 Pekanbaru is better than teaching speaking before using realia. Thus, at MTs Muhammadiyah 1 Pekanbaru, there is a significant influence of utilizing realia on students' ability to speak English before and after being taught using realia.

Based on the findings of the research, it shows that realia had significant effect of students' on speaking ability. It can be seen that the average score of the students' ability in speaking before being taught by using realia had higher score than before being taught by using realia. There was no student in the very good category previous to being taught using realia, with a proportion of $0 \%$. Then, with a percentage of $0 \%$, no student was in the good category. There was no student in the the enough category, with a percentage of $0 \% .12$ students were in the less category, with a $100 \%$ success rate. Based on the previous explanation, the researcher determined that before being taught through realia, the average score of the students' ability to speak in English especially in describing the fevorite thing was in the less category. After being taught with realia, though, As can be seen from the table above, there was no student in the very good group, with a percentage of $0 \%$. There were two students in the good category, with a percentage of $16,7 \%$. There was no student in the enough category, with a percentage of $0 \%$, and ten students in the less category, with the percentage $83,3 \%$. Based the explanation above, the researcher concluded that the average score of the students' ability in speaking after being taught by using realia was at less category. It can be concluded that realia was successful. The success of realia might be due to the advantages of realia itself and it was suggested media to improve students speaking ability.

Moreover, there is a research findings was related to another research finding conducted by Rokhmawati (2011) about The Use of Realia to Improve Students' Speaking Ability in Procedure Text. This research was focusing on the use of Realia media to improve students' speaking skills, especially in procedure text. The results demonstrate that employing realia in teaching speaking instruction text improves the quality of the product. The use of realia could aid students in comprehending the topic and making it easier for them to communicate their thoughts. Another study discovered that the realia is appropriate for speaking tests. Previous studies that focused on Descriptive Text about the animal and Procedure Text show this. 
The main aims of this research were to determine the students scores of before being taught using realia media (pre-test), the students scores of after being taught using realia media (post-test), and whether the significance effect of realia media on students' speaking ability. The finding has indicated that the eighth grade students of the MTs Muhammadiyah 1 Pekanbaru succesfully increased students' speaking scores in English. Students score better than before using Realia. It suggests that the students require a different environment in the classroom, which is provided by the media used by the researcher in the classroom to help them overcome their obstacles in learning to speak. They were more energetic, selfassured, and enjoyed expressing their feelings openly. Moreover, the students have an enjoyable and interesting way to free in speaking which will used as materials in their speaking activities. Another significant result also had shown that the students experienced all the 5 components of speaking ability proposed by Hughes (2003) which were: pronunciation, vocabulary, grammar, fluency, and comprehension. Because they were already interested in realia media, the majority of the students were enthusiastic about the teaching and learning process. They can practice seeing things they enjoy directly without being worried of making mistakes. The conclusion may be seen in the previous chapter's statistical calculation, where the $\mathrm{P}$ value was less than 0.05 (typically less than 0.05 ).

\section{Conclusion}

The present research was designed to examine the effect of realia media on students' speaking ability at MTs Muhammdiyah 1 Pekanbaru. There are two factors in this study. They are the effect of utilizing Realia to teach English (independent variable) and the ability of students to speak English (dependent variable). According to the findings of the study, the advantages of using realia are that students become more engaged in classroom activities and enthusiastic about the learning process. The researcher concludes what has been discussed in the previous chapter as follows:

1. The score of students' speaking ability who did a pre-test before being taught using Realia at MTs Muhammadiyah 1 Pekanbaru was getting a mean score of 43.42. It concluded that the students' speaking ability was low categorized.

2. The score of students' speaking ability who did post-test after being taught using Realia at MTs Muhammadiyah 1 Pekanbaru was getting mean score of 60.92. It concluded that the students' speaking ability was low categorized.

3. From the analytical formula statistics of Wilcoxon signed-rank test, it was found that employing Realia has a significant impact on students' abilities to speak at MTs Muhammadiyah 1 Pekanbaru.

Meanwhile, there are several disadvantages to using realia, such as students having difficulty speaking unfamiliar words due to their limited vocabulary, confusion in pronouncing the word in English, and the teacher spending a significant amount of time preparing realia media to bring into the classroom if the topic of the materials does not exist in the school. After finding the result of the effect of using realia on students' speaking ability at MTs Muhammadiyah 1 Pekanbaru, the researcher would like to give some suggestions to the teacher and the other researchers. This study is one of the methods for improving students' speaking abilities. There are many media, approaches, methods, strategies, techniques, that can be found and can be used to increase students' speaking ability. Finally, the researcher needs a validation of the next researcher that has the same topic. It means that realia media can be used in the other school to know the effect in teaching speaking too. Also, this research can be relevant research for the next research.

\section{References}

Amumpuni, R. S., \& Rahmasari, B. S. (2019). Enhancing students speaking ability by using realia. JPE (Jurnal Pendidikan Edutama), VI (1), 59-64. 
Arthur Hughes. (2003). Testing for language teachers. United Kingdom: Cambridge University Press.

Ary, D., Jacobs, L. C., Sorensen, C., \& Razavieh, A. (2010). Introduction to research in education. Belmont: Wadsworth.

Bala, E. (2015). The positive effects of realia in EFL classes. Department of English Language Teaching, $1-7$.

Brown, H. D. (2004). Language assessment: Principle and classroom practices. San Fransisco: Pearson Education, Inc.

Chan, W. M., Chin, K. N., Nagami, M. (2011). Media in foreign language teaching and learning. Singapore: Walter de Gruyter.

Creswell, J. W. (2012). Educational research: Planning, conducting and evaluating quantitative and qualitative research. Boston: Pearson Education.

Davies, P. M., \& Pearse, E. (2000). Success in english teaching. Oxford: Oxford University Press.

Dictionary, O. (2011). Oxford: Learner's Pocket Dictionary. UK: Oxford University Press, Inc.

Fajariyah, A., \& Yulia, Y. (2019). The Use of Realia in Teaching Speaking Skills for the Fourth Grades at SDN Karanganyar Gunung Kidul. JELLT , 1.

French, V., (1983), Techniques in Teaching Vocabulary, Oxford: Oxford University Press.

Hadi, AlnourSabitAbdelkarim. (2018). Effectiveness of Using Realia in Teaching English Vocabulary for ESL Learners'. Jzan University: International Journal of Enginerring Science Invention (IJESI)

Harmawan, V., \& Amri, Z. (2018). Using realia to improve students' speaking ability in junior. Journal of English Language Teaching, 106-111.

Harmer, J. (2001). The Practice of English Language Teaching. Cambridge: Longman.

Hunt, A. and Beglar, D., (1998). Current Research and Practice in Teaching Vocabulary

Mulyani, E. (2015). The use of realia to improve students' speaking skill. Undergraduate Thesis (p. 135). Salatiga: IAIN SALATIGA.

Permendikbud. (2018). Peraturan Menteri Kebudayaan Republik Indonesia NO 37 Tahun 2018. Jakarta, Jakarta, Indonesia.

Rokhmawati, E. (2011). The Use of Realia to Improve Students' Speaking Ability in Procedure Text ( A Classroom Action Research with the ninth-grade students of MTS Mathalibul Huda Mlonggo Jepara in the academic year of 2010/2011. Undergraduate Thesis. Jepara: IAIN Walisongo. 
Siregar, N. A., \& Anwar, D. (2019). Implementing learning community strategy to improve students speaking ability in junior high school. Journal of English Language Teaching, 393-398.

Soames, C. (2010). Using realia in the classroom. Diambil kembali dari ezinearticles:http://ezinearticles.com/?Using-Realia-in-the Classroom\&id=3937314.

Sudrajat, A. (2010). Media pembelajaran. Diambil kembali dari scholar.google.com: http://akhmadsudrajat.wordpress.com.

Sugiyono. (2011). Metode penelitian pendidikan. Bandung: CV. Alfabeta. 